\title{
LMB-84 Regimen
}

National Cancer Institute

\section{Source}

National Cancer Institute. LMB-84 Regimen. NCI Thesaurus. Code C63619.

A regimen consisting of five phases, used for the treatment of adult $L 3$ acute lymphoblastic leukemia (ALL3 or Burkitt's-type) and adult small non-cleaved cell (Burkitt's) lymphoma. The five phases include: cytoreduction, induction given as two consecutive courses, consolidation and maintenance. This particular regimen differs from other LMB/SFOP (B-cell non-Hodgkin lymphoma and B-ALL/Societe Francaise Oncologie Pediatrique) protocols because of changes to the maintenance regimen regarding the drugs used and the duration of the maintenance phase. Both the LMB 81 and LMB 89 Group B protocols follow a similar regimen to that outlined in the LMB 84 regimen. 